\title{
Impact of Governance on Profitability, Liquidity and Gearing of Companies
}

\author{
Nakiran Rajangam ${ }^{1}$, Sheela Devi D. Sundarasen ${ }^{2} \&$ Usha Rajagopalan $^{1}$ \\ ${ }^{1}$ Taylor's Business School, Taylor's University, Sunway, Malaysia \\ ${ }^{2}$ Graduate School of Management, Multimedia University, Cyberjaya, Malaysia \\ Correspondence: Nakiran Rajangam, Taylor's Business School, Taylor's University, Jalan Taylor's, 47500 \\ Subang Jaya, Selangor, Malaysia. Tel: 60-3-5629-5000. E-mail: kir7595@gmail.com
}

Received: January 14, 2014 Accepted: March 26, 2014 Online Published: April 29, 2014

doi:10.5539/ass.v10n10p13 URL: http://dx.doi.org/10.5539/ass.v10n10p13

\begin{abstract}
This study investigates the relationship between two governance issues, i.e., ownership and board structure of Malaysian listed firms (between 2010 and 2012) and their performance in terms of profitability, liquidity and gearing. Structural Equation Modeling is applied and the data analysis tool used is Maximum Likelihood Estimation (MLE). The dependent variables used as proxies for financial performance are; profitability, liquidity and gearing, whilst the independent variables are; ownership retention (OR), board size (BS), percentage of executive directors (ED), percentage of independent directors (ID) and percentage of non-independent non-executive directors (NINED). It is conjectured that there is consistency across all components of ownership and board structure in terms of its relationship with the gearing of companies. With the exception of non-independent non-executive directors, all other components of board structure in this study seem to have an impact on the gearing of companies. In that respect, it can be concluded that a company's ownership structure and board of directors who represent the shareholders have major concerns on the gearing of companies compared to other financial indicators, as the level of gearing of a company has important and long-lasting effects on the profitability and liquidity of companies. This study leads the path for further research on all aspects of a company's gearing.
\end{abstract}

Keywords: ownership structure, board structure, performance, gearing

\section{Introduction}

The corporate governance study covers a wide variety of governance topics, which includes board structure, governance of capital markets, directors' remuneration and perks, agency cost, etc. As part of the regulatory reforms post Asian Financial Crisis, Securities Commission Malaysia (capital market regulatory body) initiated certain reforms which include regulations pertaining to Bursa Malaysia listing. Malaysian Code of Corporate Governance (MCCG) was incorporated into the listing requirements, with the intention of having a more structured and impactful listing requirement, for the benefit of all stakeholders. In addition, Malaysian Watchdog Group (MSWG) was also set-up to further enhance supervision on institutional investors, simultaneously protecting the minorities. The Malaysian Code of Corporate Governance (MCCG) was updated in 2007 and 2012 as part of the regulatory body's efforts in conveying the importance of corporate governance for listed companies and to increase transparency and investor confidence.

The definition of corporate governance differs, depending on one's interpretation. From a broad perspective, Zingales (1998) views governance structure as "the complex set of constraints that shape the ex-post bargaining over the quasi-rents developed by the firm”. Shleifer \& Vishny (1997) characterizes corporate governance as the "ways in which suppliers of investment to companies guarantee themselves of getting a return on their investment", whilst Gillan \& Starks (1998) characterizes corporate governance as "the system of rules, regulations and features that regulate procedures".

Emphasis on governance has received considerable attention globally and it is utmost important for researchers to investigate the presence and impact of governance on companies performances. In that context, this study intends to explore the relationship between two governance issues, i.e., ownership and board structure of Malaysian listed firms (between 2010 and 2012) and their performance in terms of profitability, liquidity and 
gearing. The following section gives an overview of the two major areas of this study, i.e., function of ownership retention and board structure on the performance of a company.

\section{Literature Review}

Literature documents that "internal governance" can be analysed from four main scopes, i.e., issues related to board of directors, ownership, managerial compensation and benefits and rights attached to shareholders. In this study, we envision to take a step further into analyzing the implication of ownership and board structure on a company's performance in terms of profitability, liquidity and gearing and not just on the return on equity (ROE), return on asset (ROA) or Tobin's $\mathrm{Q}$ as undertaken by most of the existing literature. The rational being; liquidity is widely accepted as the life-wire of a company (alongside profitability) and the financing structure (combination of debt and equity financing) plays a pivotal role in this aspect.

\subsection{Ownership Structure}

In all business ventures, be it private or state-owned companies, the structure of the ownership play an undeniably important role in the performance of these companies as they are the main decision makers and business model setters. Shleifer \& Vishny (1986) claim that companies with high proportion of institutional investors have a tendency to perform better, as they have the aptitude and financial interest to monitor the performance of corporate managers more intensively. This mitigates adverse effects arising from agency cost and thus improves the financial performance of companies. McConnell and Servaes (1990) recognized a curvilinear association between insider ownership and company performance. Similarly, Hill \& Snell (1989) concurred to the fact that ownership structures of companies have an impact on company performance. Their study was based on 122 Fortune500 firms.

Baek et al. (2004) utilized Korean data to determine firm values. They find that companies that have substantial foreign shareholdings perform better during times of crisis compared to Chaebol companies. These Chaebol companies are well known to have a high concentration of owner-managers, thus increasing the possibilities of agency conflicts and acts of expropriation at the expense of minority shareholders, ultimately affecting the performance of the businesses. However, Leung and Horwitz's (2010) study on the association between ownership structure and firm performance of Hong Kong companies (post-Asian Financial Crisis: 1997-1998) documents that Hong Kong companies practice rigorous administration and the equity ownership are held predominantly by non-executive directors. This creates a more effective orientation and alignment between insiders and outside shareholders, simultaneously enhancing company performance. It also mitigates undesirable expropriation by insiders.

Martikainen et al. (2009) investigates on family-owned enterprises and finds that S\&P500 firms that are controlled by families are more ingenious in their administration and subsequently perform better than their counterparts. In contrary, Norwegian companies document a negative relationship between family ownership and firm performance, especially in situations where the main decision-makers are family members (Barth et al., 2005). This is supported by the findings of Koke \& Renneboog (2005), whereby they concur that the presence of substantial external shareholders positively influences firm performance amongst UK companies.

Recent studies have incorporated financial structure and law into the governance structure of firms. Anderson \& Gupta (2009) documents that firms are in a better financial position when its governance structure considers the expectations of a country's financial architecture and legal demands. Based on Australian companies, Tian \& Twite (2011) find that internal governance mechanism, i.e., efficient boards and larger CEO remuneration (in terms of stock options) to be more effective mechanisms for improving firm performance compared to ownership structure. In the Malaysian front, Wahab et al. (2007) studies on governance and company performance between 1999 and 2003. The empirical findings of the study conjectures that institutional ownership have a positive impact on governance compliance (which subsequently affects performance), whilst politically connected firms slack in their compliance to governance. Nevertheless, the adverse effects of political connection on corporate governance are mitigated by institutional ownership. In conclusion, ownership structure plays a pivotal role on the performance of companies world-wide, thus warranting a more rigorous study on this issue. The following section will discuss on the existing literature pertaining to board structure and its impact on firm performance.

\subsection{Board Structure}

This section discusses the impact of board structure on firms' profitability, liquidity and gearing. In this context, numerous studies find a negative association between firm performance and board size, whilst non-executive directors positively affect firm valuation. Literature suggests that companies with small board size perform better 
as they are able to monitor effectively the performance of board members and existence of a better relationship amongst board members. It is also documented that board size and the composition of the board members have a positive impact on governance efficiency (Lin et al., 2003). Furthermore, Jensen (1993) and Lipton and Lorsch (1992) contends that bigger board sizes have high probability of unaligned directors and this negatively affects efficient decision making and control, which ultimately affects performance. Large boards are normally led by domineering Chief Executive Officer (CEO) who suppress plans, constructive discussions and productive decision-making (Jensen, 1993). Similarly, Yermack (1996) and Conyon and Peck (1998) have documented evidence that companies with smaller boards have higher performance measurements. Boo \& Sharma (2008), Bushman et al. (2004) and Vafeas, (2000) have quoted "potential free riding, failure in proper communication and inefficient decision-making" as the cause for the inverse association between board size and performance.

Studies on the impact of board size on firm performance is also undertaken by Eisenberg et al. (1998) and they suggests that larger boards are associated with lower performance because of the dispersion in administrative duties and poor accountability of individual directors compared to smaller boards where the board members are more accountable to the tasks assigned. Furthermore, smaller boards have lesser bureaucratic difficulties and thus are more decisive and industrious. Similarly, Mak and Kusnadi (2005) examine the influence of board size of Singaporean and Malaysian companies on firm performance and discovers an inverse relationship. However, Coles et al. (2008) disputes these contentions and finds that convoluted firms have bigger boards with more independent directors and have a positive impact on performance. Similarly, Chiang, (2005) discover a positive relationship between board size and firm performance. Interestingly, Kiel \& Nicholson (2003) ascertains an "inverted U" relationship between board size and firm performance, whereby any increase of board members will have an advantage only to a certain level, after which the benefits decline.

Literature on board structure has also been looked into from the perspectives of "board self-reliance". Board self-reliance is said to supposedly provide protection against the manipulative behavior of controlling shareholders and directors. "Independence" has been used by corporate governance codes as having "no relationships or circumstances which could affect the director's decision" (Mallin, 2007, p. 102). Therefore, independent directors play a pivotal role in effective monitoring (Fama \& Jensen, 1983; Johnson, Dally, \& Ellstrand, 1996). Studies undertaken in China reveal those external directors (in other words, independent directors) have a positive impact on firm performance, implying a dynamic role executed by these directors (Peng, 2004). Chen, Firth, Gao, \& Rui, (2006) also documents that external/independent directors act as effective monitors, mainly to mitigate expropriation and corporate deceptions. Independent directors are found to be more assertive in dealing with board decisions and thus create a check and balance to the undertakings of internal/executive directors (Johnson et al., 1996; Mallin, 2007). These independent directors are also in a position to share their expertise and experiences external to the firm and thus contribute positively towards firm performance (Hillman \& Dalziel, 2003).

Similarly, Boo and Sharma (2008) proposed that independent directors monitor the company performance more effectively due to the financial interest in the company. Bedard \& Johnstone (2004) also conjecture that the presence of independent board members increases the vigilance of board scrutiny. Independent directors also closely observe and challenge management decisions and policies (Abbott et al., 2004; Klein, 2002). Bhagat \& Bolton (2008) researched on the associations among governance, performance, and capital and ownership structure. Their results suggest that ownership of board members improves corporate governance, but an adverse effect is documented between board independence and performance. Based on Malaysian listed companies, Leng (2004) analyzed the impact of non-executive directors, ownership, CEO role and firm characteristics on firm performance. It is discovered that firm size, gearing and institutional shareholding significantly affect firm performance.

In conclusion, the importance of ownership and board structure cannot be disputed, but the impact of it on the performance of a company varies between countries and that gives a justification for more research to be carried out in this area. While ownership, board structure and performance have been examined previously, our research is one of the few studies that explicitly investigate the relationship between ownership and board structure on three different areas of performance, i.e., profitability, liquidity and gearing. We thus believe that it will contribute to the extant literature on the relevance of ownership and board structure of an emerging country on the three key determinants of performance, and not just profitability per se.

Drawing substantially from the above literature, we are principally involved in analyzing two key issues, i.e., the impact of ownership and board structure on the profitability, liquidity and gearing of Bursa Malaysia companies for the period 2010-2012. 


\section{Methodology}

This research uses eight hundred and sixty four publicly listed companies in Malaysia for each period of study: 2010 to 2012. This study period is selected to minimize the effects of the Global Financial Crisis (2007-2010) and to take into account the effects of Malaysian Corporate Governance Act 2007. To ensure reliability in the database, companies with missing information are omitted. The variables used in this study are as shown in Table 1.

Table 1. Board structure, profitability, liquidity and gearing indicators

\begin{tabular}{llll}
\hline Ownership/Board Structure & Profitability indicators & Liquidity indicators & Gearing indicators \\
\hline Ownership Structure & Return of Equity (ROE) & Current Ratio & Leverage ratio \\
Board Size & Return on Assets (ROA) & Cash-flow to debt ratio & Debt to equity \\
Executive Directors & & & Long-term debt to equity \\
Independent Directors & & & \\
$\begin{array}{l}\text { Non-independent } \\
\text { non-executive directors }\end{array}$ & & & \\
\hline
\end{tabular}

Structural Equation Modeling is applied as the data analysis tool by using Maximum Likelihood Estimation (MLE). SEM is adopted as it is very flexible when dealt with single or multiple linear regressions and has a systematic regression equation. Path diagrams and the calculation of direct, indirect and total effects can be more visible through the application of SEM (Edwards \& Bagozzi, 2000). As the model (Figure 1) is structured in terms of path diagram, Structural Equation Models is applied to represent the relationship between the latent variables of interest, and their manifest or observable indicators. The dependent variables used as proxies for financial performance are; profitability, liquidity and gearing, whilst the independent variables are; ownership retention (OR), board size (BS), percentage of executive directors (ED), the percentage of independent directors (ID) and percentage of non-independent non-executive directors (NINED).

Ownership structure refers to the fraction of shares held by the original owners or corporate insiders. Board size is measured by the number of directors on the board. As for the executive directors, it is measured as a percentage of total directors. Similarly, the independent directors and the non-independent non-executive directors are taken as a percentage to total directors respectively. The measure of profitability is return on equity and return on assets whilst the liquidity positions of the companies are represented by current ratio and cash flow to debt ratio. The gearing of the company is based on the leverage ratio, long-term debt to capital and the debt to equity ratio. All these data/measurements are taken directly from Datastream.

The regression equation is as shown below;

$$
\begin{gathered}
\text { Profitability }_{i t}=\beta_{0}+\beta_{1} \mathrm{OR}_{\mathrm{it}}+\beta_{2} \mathrm{BS}_{\mathrm{it}}+\beta_{3} \mathrm{ED}_{\mathrm{it}}+\beta_{5} \mathrm{ID}_{\mathrm{it}}+\mathrm{NINED}_{\mathrm{it}}+\varepsilon_{\mathrm{it}} \\
\text { Liquidity }_{\mathrm{it}}=\beta_{0}+\beta_{1} \mathrm{OR}_{\mathrm{it}}+\beta_{2} \mathrm{BSS}_{\mathrm{it}}+\beta_{3} \mathrm{ED}_{\mathrm{it}}+\beta_{5} \mathrm{ID}_{\mathrm{it}}+\mathrm{NINDD}_{\mathrm{it}}+\varepsilon_{\mathrm{it}} \\
\text { Gearing }_{\mathrm{it}}=\beta_{0}+\beta_{1} \mathrm{OR}_{\mathrm{it}}+\beta_{2} \mathrm{BS}_{\mathrm{it}}+\beta_{3} \mathrm{ED}_{\mathrm{it}}+\beta_{5} \mathrm{ID}_{\mathrm{it}}+\mathrm{NINED}_{\mathrm{it}}+\varepsilon_{\mathrm{it}}
\end{gathered}
$$

Where;

$\mathrm{OR}_{\mathrm{it}}=$ Ownership structure of company $\mathrm{i}$ at year $\mathrm{t}$;

$\mathrm{BS}_{\mathrm{it}}=$ Board Size of company $\mathrm{i}$ at year $\mathrm{t}$;

$\mathrm{ED}_{\mathrm{it}}=$ Executive Directors of company $\mathrm{i}$ at year $\mathrm{t}$;

$\mathrm{ID}_{\mathrm{it}}=$ Independent Directors of company $\mathrm{i}$ at year $\mathrm{t}$;

$\mathrm{NINED}_{\text {it }}=$ Non-independent non-executive Directors of company $\mathrm{i}$ at year $\mathrm{t}$. 


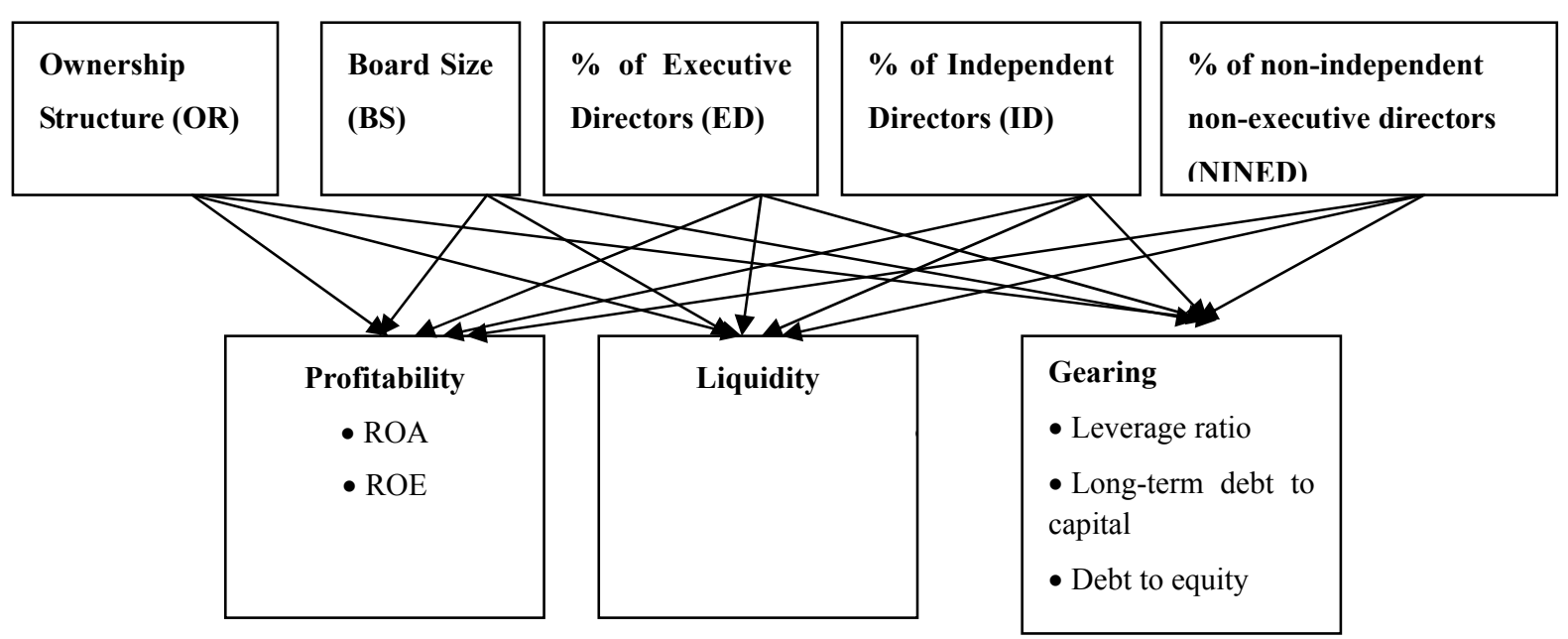

Figure 1. The conceptual framework of board structure and their impact on firms' financial performance

\section{Data Analysis and Discussion}

Table 2. Regression results on the relationship between ownership structure and the profitability, liquidity and gearing ratio of Bursa Malaysia companies from 2010-2012

\begin{tabular}{llllllll}
\hline & ROA & ROE & CR & CFD & LR & DE & LTDC \\
\hline Ownership & 0.089 & $0.665^{* * *}$ & $0.164^{* *}$ & -0.042 & $-0.954^{* *}$ & $-0.964^{* *}$ & $-0.951^{* *}$ \\
Structure & $(0.223)$ & $(0.000)$ & $(0.025)$ & $(0.573)$ & $(0.000)$ & $(0.000)$ & $(0.000)$ \\
\hline$* * *$ sign)
\end{tabular}

***significant at $1 \%$ level; figures in parenthesis are the $\mathrm{p}$-value;

Profitability: ROA-Return on Equity; ROA-Return on Assets;

Liquidity: CR-Current Ratio; CFD-Cash flow to Debt;

Gearing: LR-Leverage Ratio; DE-Debt to Equity; LTDC-Long-term Debt to Capital.

In general, the empirical results indicate that the ownership structure of a company has a positive significant impact ( $\mathrm{p}$-value $=0.000$ ) on the profitability, whilst a negative significant impact is noted for liquidity and gearing (p-value 0.025 for current ratio) and a p-value of 0.000 for all proxies of gearing. The results show that ownership structure is able to exert significant influence over firm performance, from all perspectives. High retention of ownership by the founder members or corporate ownership seems to increase the profitability of a company in general. This could mainly be due to the vested financial interest of the founders. High corporate ownership also seems to have a positive impact on Malaysian companies and it may be due to several factors such as insider information, political connection etc.

Nevertheless, high ownership retention and corporate ownership indicates lower liquidity. As for gearing, the results indicate that an increase in ownership by the founders or corporate retention reduces the gearing of a company. Generally, this is considered good for a company because gearing is highly associated with risk and it can be conjectured that companies with high founder and corporate retention are more risk averse, more so after the Asian and global financial crisis. 


\subsection{Board Size and Financial Performance}

Table 3. Regression results on the relationship between board size and the profitability, liquidity and gearing ratio of Bursa Malaysia companies from 2010-2012

\begin{tabular}{llllllll}
\hline & ROA & ROE & CR & CFD & LR & DE & LTDC \\
\hline Board Size & -0.019 & -0.075 & -0.057 & -0.092 & $-0.045^{* *}$ & $-0.049^{* *}$ & $-0.012^{* *}$ \\
& $(0.800)$ & $(0.169)$ & $(0.438)$ & $(0.217)$ & $(0.032)$ & $(0.023)$ & $(0.518)$ \\
\hline
\end{tabular}

**significant at $5 \%$ level; figures in parenthesis are the p-value;

Profitability: ROA-Return on Equity; ROA-Return on Assets;

Liquidity: CR-Current Ratio; CFD-Cash flow to Debt;

Gearing: LR-Leverage Ratio; DE-Debt to Equity; LTDC-Long-term Debt to Capital.

Board size refers to the total number of directors in a company. The empirical results above show no significance on the relationship among board size and companies' profitability and liquidity. Nevertheless, a significantly negative relationship at $5 \%$ level is documented between board size and the gearing of companies. It shows a coefficient of $-0.045,-0.049$ and -0.012 respectively for the leverage, and debt to equity and long-term debt to capital ratio. The capital structure of a company plays a pivotal role in the overall financial performance of any company as it has an impact on the profitability and liquidity. Large boards with wider spectrum of expertise have more room to effectively monitor the gearing to ensure an optimal debt-equity structure due to its nature of importance on other financial performance.

\subsection{Executive Directors and Financial Performance}

Table 4. Regression results on the relationship between executive and the profitability, liquidity and gearing ratio of Bursa Malaysia companies from 2010-2012

\begin{tabular}{llllllll}
\hline & ROA & ROE & CR & CFD & LR & DE & LTDC \\
\hline Executive Directors & $0.162^{* *}$ & $0.115^{* *}$ & 0.102 & -0.114 & $-0.120^{* * *}$ & $-0.122^{* * *}$ & $-0.097^{* * *}$ \\
& $(0.026)$ & $(0.034)$ & $(0.162)$ & $(0.126)$ & $(0.000)$ & $(0.000)$ & $(0.000)$ \\
\hline
\end{tabular}

**significant at $5 \%$ level ***;

Significant at $1 \%$ level; figures in parenthesis are the p-value;

Profitability: ROA-Return on Equity; ROA-Return on Assets;

Liquidity: CR-Current Ratio; CFD-Cashflow to Debt;

Gearing: LR-Leverage Ratio; DE-Debt to Equity; LTDC-Long-term Debt to Capital.

Executive directors are directors who are actively involved in the running of the business. Executive directors can be classified into independent executive directors and non-independent executive directors. The findings above show the impact of executive directors (both independent executive directors and non-independent executive directors) on the profitability, liquidity and gearing of companies. The results indicate a significantly positive relationship between the percentage of executive directors' representation in a board and the profitability of companies, whilst a significantly negative relationship is denoted for the gearing of companies. No significant relationship is denoted for liquidity. The coefficient for the relationship between executive directors and the return on assets and return on equity are 0.162 and 0.115 respectively. As for the gearing, the coefficients are $-0.120,-0.122$ and -0.097 respectively, for the leverage, debt to equity and long-term debt to capital ratio.

Boards with a higher percentage of executive directors are expected to provide more helpful advice and know-how in evaluating new strategies. Based on the empirical findings, this study conjectures that executive directors play a critical role in ensuring the profitability for companies and thus, maximize shareholders' value. Therefore, it is vital that shareholders are selective in identifying the most appropriate and talented executive directors of a company as these executive directors act as a link between the shareholders and the operational managers. Furthermore, the positive association could also be due to the financial interest the executive directors have in a company. 


\subsection{Independent Directors and Financial Performance}

Table 5. Regression results on the relationship between independent directors and the profitability, liquidity and gearing ratio of Bursa Malaysia companies from 2010-2012

\begin{tabular}{llllllll}
\hline & ROA & ROE & CR & CFD & LR & DE & LTDC \\
\hline Independent Directors & 0.038 & -0.045 & -0.061 & -0.066 & $-0.121^{* * *}$ & $-0.122^{* * *}$ & $-0.115^{* * *}$ \\
& $(0.605)$ & $(0.404)$ & $(0.398)$ & $(0.372)$ & $(0.000)$ & $(0.000)$ & $(0.000)$ \\
\hline
\end{tabular}

***significant at $1 \%$ level; figures in parenthesis are the $\mathrm{p}$-value;

Profitability: ROA-Return on Equity; ROA-Return on Assets;

Liquidity: CR-Current Ratio; CFD- Cashflow to Debt;

Gearing: LR-Leverage Ratio; DE-Debt to Equity; LTDC-Long-term Debt to Capital.

An independent director normally acts as an advisor for companies since he or she has many years of experience. Their role predominantly includes improving corporate credibility and governance standards, function as watchdog and play a vital role in risk management. They normally represent various committees to ensure good governance. The findings of this study shows no relationship between the independent directors and profitability and liquidity positions of companies but a significantly negative relationship exist between independent directors and gearing of companies. The coefficients are $-0.121,-0.122$ and -0.115 respectively for the leverage, debt to equity and long-term debt to capital ratio. Companies with a high percentage of independent directors seem to have low gearing. As stated above, the independent directors are experienced individuals engaged by the main shareholders of companies to act as watchdog. In that context, independent directors play a critical role in ensuring the gearing of companies as it has a tremendous impact on the survival of companies. As for the insignificance on the profitability, it could be due to the independent directors not having access to adequate information about the firm and, because of their prime work obligations, having restricted time to commit to their directorship demands. Baliga et al. (1996) and Bhagat and Black (1999) also discovered no clues that the occurrence of non-executive independent directors contributes to better functioning or market performance, and some research even concludes that a larger percentage of independent controllers is negatively associated with firm performance (Klein, 1998; Yermack, 1996). Nevertheless, it is important to enhance the number of independent directors on corporate boarsds to advance board independence.

\subsection{Non-Independent Non-Executive Directors and Financial Performance}

Table 6. Regression results on the relationship between non-independent non-executive directors and the profitability, liquidity and gearing ratio of Bursa Malaysia companies from 2010-2012

\begin{tabular}{lllllllll}
\hline & ROA & ROE & CR & CFD & LR & DE & LTDC \\
\hline Non-independent non-executive directors & 0.12 & 0.068 & 0.062 & 0.033 & 0.022 & 0.021 & 0.025 \\
& $(0.869)$ & $(0.211)$ & $(0.399)$ & $(0.66)$ & $(0.292)$ & $(0.322)$ & $(0.19)$ \\
\hline
\end{tabular}

Figures in parenthesis are the p-value;

Profitability: ROA-Return on Equity; ROA-Return on Assets;

Liquidity: CR-Current Ratio; CFD-Cashflow to Debt;

Gearing: LR-Leverage Ratio; DE-Debt to Equity; LTDC-Long-term Debt to Capital.

Non-executive directors indicate that the directors are not involved in the running of the company whilst non-independently refers to the relationship between the ownership of the company and the directors. Therefore, non-independent non-executive directors are directors who have family relationship with the original owners of the companies, but they are not involved in the running of the business. The above results indicate that there is no relationship between the role of non-independent non-executive directors with the profitability, liquidity and gearing of the company. 


\section{Conclusion}

This study tests a conceptual framework to establish the significance of ownership and board structure on Malaysian companies' financial performance from three main perspectives, i.e., the profitability, liquidity and gearing. Ownership structure refers to the retention of ownership by the original founders of the business or a high percentage of corporate ownership. Board size, executive directors, independent directors and non-independent non-executive directors are identified as representing board structure. Results indicate that ownership structure and board size have an impact on the profitability and gearing, whilst executive directors and independent directors have an impact only on the gearing of a company. Non-independent non-executive directors do not seem to have any relationship with the performance indicators of this study.

Thus, our study contributes to the literature by offering additional evidence on whether intensified ownership and governance attributes (in terms of board structure) are supportive or detrimental to firm performance in terms of profitability, liquidity and gearing. The main contribution of this study will be the fact that there is consistency across all components of ownership and board structure in terms of its relationship with the gearing of companies. With the exception of non-independent non-executive directors, all other components of board structure in this study seem to have an impact on the gearing of a company. In that respect, it can be conjectured that a company's ownership structure and board of directors who represent the shareholders have major concerns on the gearing of the company compared to other financial indicators. This could be due to the contagion effect gearing may have on profitability and liquidity, which is pivotal for the survival of a company and also for the purpose of meeting the main objectives of shareholder maximization. Therefore, we conjecture that ownership and board structure is generally important for the well-being of a company. In summary, this study not only support to the existing literature, but also adds new perspectives and findings that are not discovered in previous research on the influence of ownership and board structure on the gearing of businesses in an emerging market. We conclude that our outcome should be of significance to policymakers and regulators who are steadfast in articulating and advancing effective and practical guidelines, with the contention of operational implementation of corporate governance. This will certainly enhance investor confidence and spiral a boost to firm performance.

\section{References}

Anderson, A., \& Gupta, P. P. (2009). A cross-country comparison of corporate governance and firm performance: Do financial structure and the legal system matter? Journal of Contemporary Accounting \& Economics, 5, 61-79. http://dx.doi.org/10.1016/j.jcae.2009.06.002

Baek et al. (2004). Corporate governance and firm value: Evidence from the Korean financial crisis. Journal of Financial Economics, 71, 265-313. http://dx.doi.org/10.1016/S0304-405X(03)00167-3

Barth, E., Gulbrandsen, T., \& Schone, P. (2005). Family ownership and productivity: The role of owner-manager. J. Corp. Finance, 11, 107-127. http://dx.doi.org/10.1016/j.jcorpfin.2004.02.001

Bhagat, S., \& Bolton, B. (2008). Corporate governance and firm performance. Journal of Corporate Finance, 14, 257-273. http://dx.doi.org/10.1016/j.jcorpfin.2008.03.006

Boo, E., \& Sharma, D. (2008). Effect of regulatory oversight on the association between internal governance characteristics and audit fees. Journal of Accounting and Finance, 48(1), 51-71. http://dx.doi.org/10.1111/j.1467-629X.2007.00229.x

Borokhovich, K. A., Parrino, R., \& Trapani, T. (1996). Outside directors and CEO selection. Journal of Financial Quantitative Analysis, 31, 337-355. http://dx.doi.org/10.2307/2331395

Chen, G., Firth, M., Gao, D. N., \& Rui, O. M. (2006). Ownership structure, corporate governance and fraud: Evidence from China. Journal of Corporate Finance, 12(3), 424-448. http://dx.doi.org/10.1016/j.jcorpfin.2005.09.002

Chiang, H. (2005). An Empirical Study of Corporate Governance and Corporate Performance. The Journal of American Academy of Business, 6(1), 95-101.

Coles, J. L., Daniel, N. D., \& Naveen, L. (2008). Boards: Does one size fit all? Journal of Financial Economics, 87, 329-356. http://dx.doi.org/10.1016/j.jfineco.2006.08.008

Conyon, M., \& Peck, S. (1998). Board size and corporate performance: Evidence from European countries. European Journal of Finance, 4, 291-304. http://dx.doi.org/10.1080/135184798337317

Edwards, J. R., \& Bagozzi, R. P. (2000). On the nature and direction of relationships between constructs and measures. Psychological Methods, 5(2), 155-174. http://dx.doi.org/10.1037/1082-989X.5.2.155 
Gillan, S. L., \& Starks, L. T. (1998). A survey of shareholder activism: Motivation and empirical evidence. Contemporary Finance Digest, 2(3), 10-34.

Haniffa, R., \& Hudaib, M. (2006). Corporate Governance Structure and Performance of Malaysian Listed Companies. Journal of Business Finance \& Accounting, 33(7-8), 1034-1062. http://dx.doi.org/10.1111/j.1468-5957.2006.00594.x

Hill, C. W., \& Snell, S. A. (1989). Effects of ownership structure and control on corporate productivity. Acad. Manage. J., 32, 25-46. http://dx.doi.org/10.2307/256418

Hillman, A. J., \& Dalziel, T. (2003). Boards of directors and firm performance: Integrating agency and resource dependence perspectives. Academy of Management Review, 28, 383-396. http://dx.doi.org/10.5465/AMR.2003.10196729

Jensen, M. C. (1993). The modern industrial revolution, exit, and the failure of internal control systems. $J$. Finance, 48, 831-880. http://dx.doi.org/10.1111/j.1540-6261.1993.tb04022.x

Koke, J., \& Renneboog, L. (2005). Do corporate control and product market competition lead to stronger productivity growth? Evidence from market-oriented and block holder-based governance regimes. J. Law Economics, 48, 475-516. http://dx.doi.org/10.1086/428019

La Porta, R., Lopez-de-Silanes, F., Shleifer, A., \& Vishny, R. (2000). Investor protection and corporate governance. Journal of Financial Economics, 58, 3-27. http://dx.doi.org/10.1016/S0304-405X(00)00065-9

Leng, C. A. (2004). The Impact of Corporate Governance Practices on Firms' Financial Performance: Evidence from Malaysian Companies. ASEAN Economic Bulletin, 21(3), 308-318. http://dx.doi.org/10.1355/AE21-3D

Leora, F., Klapper, \& Love, I. (2004). Corporate governance, investor protection, and performance in emerging markets. Journal of Corporate Finance, 10, 703-728. http://dx.doi.org/10.1016/S0929-1199(03)00046-4

Leung, S., \& Horwitz, B. (2010). Corporate governance and firm value during a financial crisis. Review of Quarterly Financial Accounting, 34, 459-481. http://dx.doi.org/10.1007/s11156-009-0141-z

Lipton, M., \& Lorsch, J. W. (1992). A modest proposal for improved corporate governance. Business Lawyer, 48, 59-77.

Mak, Y. T., \& Kusnadi, Y. (2005). Size Really Matters: Further Evidence on the Negative Relationship between Board Size and Firm Value. Pacific Basin Finance Journal, 13(3), 301-318. http://dx.doi.org/10.1016/j.pacfin.2004.09.002

Mallin, C. (2007). Corporate governance (2nd ed.). Oxford University Press: Oxford.

Martikainen, M., Nikkinen, J., \& Vahamaa, S. (2009). Production functions and productivity of family firms: Evidence from the S\&P500. Q. Rev. Econ. Finance, 49, 295-307. http://dx.doi.org/10.1016/j.qref.2007.11.001

McConnell, J. J., \& Servaes, H. (1990). Additional Evidence on Equity Ownership and Corporate Value. Journal of Financial Economics, 27(2), 595-613. http://dx.doi.org/10.1016/0304-405X(90)90069-C

Mitton, T. (2002). A cross-firm analysis of the impact of corporate governance on the East Asian financial crisis. Journal of Financial Economics, 64, 215-241. http://dx.doi.org/10.1016/S0304-405X(02)00076-4

Morck, R. K., Shleifer, A., \& Vishny, R. W. (1988). Management ownership and market valuation: An empirical analysis. J. Financ. Economics, 20, 293-315. http://dx.doi.org/10.1016/0304-405X(88)90048-7

Nicholson, Gavin, J., \& Kiel, G. C. (2003). Board Composition and Corporate Performance: How the Australian Experience Informs Contrasting Theories of Corporate Governance. Corporate Governance: An International Review, 11(3), 189-205. http://dx.doi.org/10.1111/1467-8683.00318

Palia, D., \& Lichtenberg, F. (1999). Managerial ownership and firm performance: A re-examination using productivity measurement. J. Corp. Finance, 5, 323-339. http://dx.doi.org/10.1016/S0929-1199(99)00009-7

Pfeffer, J., \& Salancik, G. R. (1978). The external control of organizations. New York: Harper \& Row.

Shleifer, A., \& Vishny, R. W. (1986). Large Shareholders and Corporate Control. Journal of Political Economy, 95, 461-488. http://dx.doi.org/10.1086/261385

Tian, G. Y., \& Twite, G. (2011). Corporate governance, external market discipline and firm productivity. Journal of Corporate Finance, 17, 403-417. http://dx.doi.org/10.1016/j.jcorpfin.2010.12.004 
Wahab, Junice, C. Y., \& Verhoeven, P. (2007). The Impact of the Malaysian Code on Corporate Governance: Compliance, Institutional Investors and Stock Performance. Journal of Contemporary Accounting \& Economics, 3(2). http://dx.doi.org/10.1016/S1815-5669(10)70025-4

Yermack, D. (1996). Higher market valuation for firms with a small board of directors. Journal of Financial Economics, 40, 185-211. http://dx.doi.org/10.1016/0304-405X(95)00844-5

Yoshikawa, T., \& McGuire, J. (2008). Change and continuity in Japanese corporate governance. Asia Pacific Journal of Management, 25, 5-24. http://dx.doi.org/10.1007/s10490-007-9064-1

Zingales. (1998). Power in a Theory of the Firm. Quarterly Journal of Economics, 113(2), 387-432.

\section{Copyrights}

Copyright for this article is retained by the author(s), with first publication rights granted to the journal.

This is an open-access article distributed under the terms and conditions of the Creative Commons Attribution license (http://creativecommons.org/licenses/by/3.0/). 